\title{
Preliminary results of fruit quality of resistant sour cherry clones in 2014
}

\author{
Vaszily, B. \\ Fruit Research and Extension Institute, Újfehértó, Hungary
}

\begin{abstract}
Summary: The richness of Hungarian sour cherry cultivars in the world is unique; they can be consumed in many ways. Sour cherry is a Hungaricum and has excellent fruit quality and nutritional value. Nowadays the demand for chemical-free fruits is increasing. Reducing the number of chemical applications can be achieved most effectively by the use of resistant varieties, technological developments and cultivar innovation. The domestic and international sour cherry breeding programs use almost exclusively the resistant 'Csengődi' clones as a basis. They are mainly Monilinia and Blumeriella resistant and have higher dry matter and antioxidant content. These pathogens influence not only the qualitative and quantitative parameters of the fruits, but may play an indirect role in the deterioration of the overall condition of the trees as well. The cultivation of resistant varieties can greatly reduce the pesticide load of the environment, so we can produce fruit with excellent nutritional value with fewer chemicals. Our aim is the expansion of the sour cherry assortment by introducing new resistant cultivars. With this we can contribute to the spreading of environmentally sound production technologies and supply "super fruits" to the consumers.
\end{abstract}

Keywords: resistant sour cherry clones, fruit quality

\section{Introduction}

The sour cherry production is in third place after apples and plums. In the 1960s Hungary produced mainly 'Pándy' and 'Cigány' cultivars. The use of sour cherry cultivars shifted to 'Újfehértói fürtös', 'Érdi bőtermő', 'Debreceni bőtermő', 'Kántorjánosi 3' in the 1990s. These cultivars determine the sour cherry production up to this day. So nowadays the assortment of cultivars is poor.

The production is quite low (3-6 t/ha) and only $15 \%$ of the current orchards can produce 10 to 15 t/ha. These low yields can be caused by inadequate plant protection, problems of the growing site and production technology (Soltész et al., 2003; Szabó, 2007; Gonda, 2010).

In the world sour cherries are consumed almost only in a processed form. Sour cherries are consumed fresh in Hungary and in some Northern-European countries, as the domestic cultivars do not contain bitter substances. Cultivar use is determined by the way of consumption (Nyéki et al., 2005; Szabó, 2007). Sour cherry producing countries grow only one or two cultivars in largest proportion. The health promotion characteristic of Hungarian sour cherries is well known.

Horkai is a regional sour cherry cultivar. Fruit has excellent characteristics (high fruit firmness, succulent, juice is painter, high acid and sugar content, great taste) and it is resistant to diseases. The origin of Horkai is unknown (Horkai, 2002).

The 'Csengődi' cultivar was bred by Apostol János. This cultivar is resistant against cherry leaf spot (Blumeriella jaapii (Rehm) Arx) and Monilinia spp. (Apostol, 1990; Holb,
2004, 2006, 2009). Csengödi clones have high antioxidant capacity. The basic cultivar 'Csengödi' has 4-5 g fruit weight, 21-22 mm fruit diameter, middle-firm and slightly elongated ball shape. Fruits ripen heterogenicly inside the trees. Stems are long and don't have stipules. The fruit-stem detachment layer is not dry. This cultivar is not producing bare wood. Blooming is middle-early, flowers are self-fertile. Fruits have high Brix\%: 16-20, acid: 1,1-3,2 g/l, stone ratio 4,5-5,5\% (Apostol, 1994, 2003, Brózik és Kállay, 2000; Soltész, 1997, 2004).

VN-1, VN-4, VN-7 clones are originating from 'Bosnyák' or 'Csengődi' cultivar. Fruits ripen in tree homogenicly, and the fruit-stem detachment layer is dry (Szabó, 2007; Szőke, 2014). Clones were selected by Szőke Ferenc. VN-4 ripens at the end of June, it has small-middle sized fruits $(4,5-5 \mathrm{~g}$ and 20-22 mm). Fruit has slightly elongated ball shape, fruit skin is thick and does not have stipules. Brix \%: 1617. Tree is vigorous, canopy is pyramidal. Trees need canopy shaping pruning. Blooming is middle-early, flowers are self-fertile. Trees turn to cropping late. The major value it's disease resistance, so it is adequate for environmentalfriendly production technology. Fruits are suitable for fresh consumption. Antioxidant capacity is high, so it can be used as a natural food coloring. 'VN1' ripens 4 days before $\mathrm{VN}-4$ and has higher fruit firmness (Szabó, 2007).

\section{Materials and methods}

The experiments were set up in Debrecen-Pallag, at the Experimental Farm of Horticulture and Regional Research 
Centre of University of Debrecen, and at the Research and Extension Centre for Fruit Growing at Újfehértó. Fruits of Csengődi clones came from Pallag, fruits of VN clones and Horkai from Újfehértó, and fruits of VN-7 clone from the orchard of Szöke Ferenc.

In this study we measured 60 fruits per clones. Fruits were harvested by hand at eating maturity stage. Fruit diameter (x), fruit width (y), fruit height (z), length of stem was measured by digital caliper (PROTECO 90.32-P200D, Czech Republic). Fruit and stone weight was measured by digital scale (CAS PRECISION MW-300T, Taiwan). Brix (\%) was measured by digital refractometer (Atago Palette PR-201, Japan) and citric acid content (0-10 g/100g) was measured by Atago Pocket PAL-29S, Japan. Anthocyanin capacity was determined by specifical photometer (UVEX Lab ML-01). Photometer has it's own index-number (PharM).

The skin color was measured by chromameter (Minolta CR-200, Japan). This displayed in $\mathrm{Y}, \mathrm{x}$ and $\mathrm{y}$ values that represent light-dark, the green-red and the blue-yellow spectrum. Higher $Y$ values correspond to lighter fruit. Low values (Y) mean darker fruit.

Fruit firmness $(\mathrm{kPa} / \mathrm{mm})$ was measured by electronic penetrometer (PSION Organiser II./MGA-1091). Fruit firmness was measured on three points of the fruit using a nondestructive head with $4 \mathrm{~mm}$ diameter.

Stem removal force was measured by Kirscehnzipper (ZIP01/2N, UP Kirschenstengel-Kraftmessgerät, Germany).

\section{Results}

In 2014 VN clones and basic 'Csengödi' cultivars produced the smallest fruits (diameter). 'Csengödi' clone had bigger size compared to basic cultivar (Table 1). The biggest of clones was Csengődi 8 (23 mm), smallest was Csengődi 4. Fruit diameter of Horkai was $22 \mathrm{~mm}$.

VN-1 had the lowest fruit weight, so were the other VN clones. 'Csengődi' clones had 5-6 g fruit weight. According to Soltész (1997), fruit size can be characterized by size categories and fruit weight. It is practical to take both of them into account, primarily because of the specific weight and shape of the fruits.

Csengödi 12 and Horkai had the lowest stone weight, VN-4 and 'Csengödi' had the highest. Other 'Csengödi' clones had 0.27-0.29 g stones, VN clones had $0.28 \mathrm{~g}$. Csengödi 12 had the lowest stone ratio, and VN-4 had the highest (it has low fruit weight and big stone). According to Soltész (1998) stone ratio is favorable if not higher than $5-6 \%$. In this respect 'Csengödi', VN-4, VN-1 clones are unfavorable, but Csengödi 12 is favorable.

Fruit width and height follow the tendency of diameter. Height of 'Csengödi' is outstanding. The three parameters that determine fruit size give shape and regularity index. According to Soltész (1997) shape index (fruit height/width) close to 1 means spheric shape. Porpáczy (1964) defined the shape index of fruit $=(($ width+diameter $) / 2) /$ height. If $<$ 0.95 longish, 0.95-1.05 spheric/round, $>1.05$ flat. Regularity index of fruit=width/diameter. If $<0.95$ rim-reduced, 0.95 1.05 regular, $>1.05$ laterally-reduced.

According to the shape index (Figure 1.), 'Csengödi' basic cultivar, VN-4 and 'Csengödi 1' clones are spheric; other clones are flat-round. By regularity index all clones and cultivars fall into the laterally-reduced category.

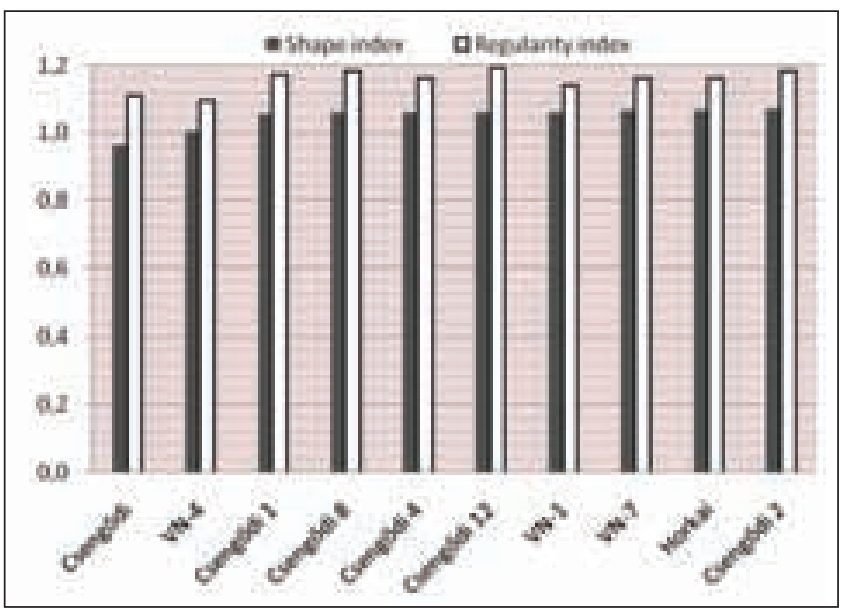

Figure 1. Shape and regularity index of resistant sour cherry clones (Pallag-Újfehértó, 2014)

Horkai and VN-7 had the lowest flesh firmness (Figure 2.), the hardest were Csengődi 8, 'Csengődi 1' and VN-4 clones. Other clones have $315-358 \mathrm{kPa} / \mathrm{mm}$ firmness. Clones had higher firmness than basic 'Csengődi' cultivar.

Horkai had the longest stems $(59 \mathrm{~mm})$, while Csengődi 2 has shortest (Table 2.). Stem detachment force doesn't correlate to stem length and time of ripening. According to Apostol (1994) stem of 'Csengödi' cultivar does not deterach from the fruit with dry abscision layer. We also experienced 
this habit. Stems of VN-7 were the easiest to detach. 'Csengödi' clones required the highest force to remove the stem $\left(648-789 \mathrm{~N} / \mathrm{mm}^{2}\right)$.

Number of stipule is typical characteristic of cultivars. All 'Csengődi' clones excluding Csengődi 12 have it. VN-7 clone had no stipule (Table 2.). VN-4 and 'Csengödi 1' had the lowest incidence of stipule (f\%). Average number of stipule was fewest in case of $\mathrm{VN}-1$. According to the literature 'Csengődi' has no stipule, but our observations were opposite. Also, 'Csengödi' clones had more stipule than the basic cultivar 'Csengődi'.

Table 2. Characteristic of stems of resistant sour cherry clones (Pallag-Debrecen, 2014)

\begin{tabular}{|l|c|c|c|c|}
\hline \multicolumn{1}{|c|}{ Cultivars } & $\begin{array}{c}\text { Length } \\
\text { of stem } \\
\text { (mm) }\end{array}$ & $\begin{array}{c}\text { Stem de- } \\
\text { tachment } \\
\text { force } \\
\left(\mathbf{N} / \mathbf{m m}^{2}\right)\end{array}$ & $\begin{array}{c}\text { Frequency } \\
\text { distribu- } \\
\text { tion of } \\
\text { stem (f\%) }\end{array}$ & $\begin{array}{c}\text { Average } \\
\text { number } \\
\text { of stipules } \\
\text { per stem }\end{array}$ \\
\hline Csengődi 2 & 45.90 & 706.45 & 10 & 1 \\
\hline VN-7 & 46.29 & 227.48 & 0 & 0 \\
\hline Csengődi 12 & 47.68 & 773.38 & 0 & 0 \\
\hline Csengődi 4 & 47.82 & 741.72 & 26.7 & 1.4 \\
\hline Csengődi 8 & 48.39 & 648.84 & 23.3 & 1 \\
\hline VN-1 & 50.85 & 358.46 & 20 & 0.5 \\
\hline Csengődi 1 & 52.18 & 798.60 & 6.7 & 1 \\
\hline VN-4 & 53.80 & 439.53 & 4 & 1 \\
\hline Csengődi & 54.58 & 312.70 & 10 & 1 \\
\hline Horkai & 58.99 & 392.86 & 12 & 1.7 \\
\hline Csengődi 8 & $\mathbf{2 3 . 0 0}$ & 19.45 & 20.07 & 5.96 \\
\hline
\end{tabular}

VN clones and 'Csengödi' basic cultivar had Brix higher than $20 \%$, and Horkai had high value, too (Figure 3.). Citric acid content follow the tendency of Brix \% values. VN-1 clone was the sourest, and Csengődi 12 clone had the lowest citric acid content. Fruits from Újfehértó orchards had citric acid content above $2 \mathrm{~g} / \mathrm{l}$, while from the Pallag orchards 1,4-1,9 g/l.

Results of the skin colour measurements are show in Table 3. 'Csengődi 1' was the darkest, Csengódi 12 and Csengödi 8 were the lightest. Differences between the clones were not significant. VN-7 and Horkai had the highest anthocyanin capacity, 'Csengődi 1' had the lowest. Csengődi 4, Csengődi 2 , and Csengődi 8 had better anthocyanin capacity when compared to the basic cultivar 'Csengődi'. These clones surpassed $\mathrm{VN}-1$ and $\mathrm{VN}-4$ clones. Out of the VN clones VN-4 had the lowest anthocyanin capacity.

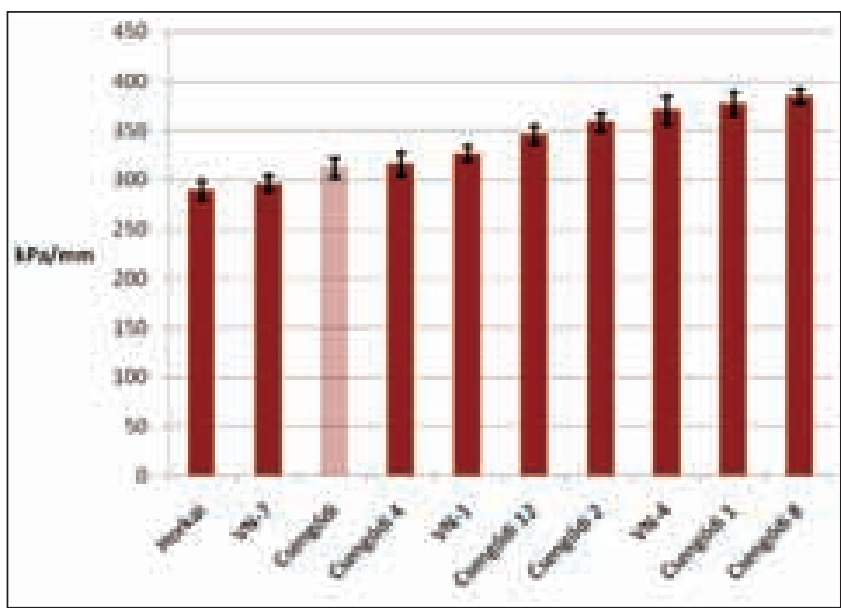

Figure 2. Flesh firmness of resistant sour cherry clones

Table 3. Fruit colour and anthocyanin capacity of resistant sour cherry cultivars (Pallag-Újfehértó, 2014)

\begin{tabular}{|l|c|c|c|c|}
\hline Cultivars & $\begin{array}{c}\text { Colour } \\
\text { coordinate } \\
(\mathbf{Y})\end{array}$ & $\begin{array}{c}\text { Colour } \\
\text { coordinate } \\
(\mathbf{x})\end{array}$ & $\begin{array}{c}\text { Colour } \\
\text { coordinate } \\
(\mathbf{y})\end{array}$ & $\begin{array}{c}\text { Antho- } \\
\text { cyanin } \\
\text { (PharM) }\end{array}$ \\
\hline Csengődi 1 & $\mathbf{5 . 1 2}$ & 0.3537 & 0.3076 & $\mathbf{5 . 3 0}$ \\
\hline Csengődi 4 & 5.29 & 0.3459 & 0.3084 & $\mathbf{8 . 1 0}$ \\
\hline VN-7 & $\mathbf{5 . 3 1}$ & 0.3260 & 0.3087 & $\mathbf{1 0 . 2 0}$ \\
\hline VN-1 & $\mathbf{5 . 4 3}$ & 0.3307 & 0.3081 & $\mathbf{6 . 2 0}$ \\
\hline Csengődi & $\mathbf{5 . 7 0}$ & 0.3400 & 0.3063 & $\mathbf{6 . 4}$ \\
\hline Horkai & 5.71 & 0.3399 & 0.3081 & $\mathbf{9 . 1 0}$ \\
\hline Csengődi 2 & $\mathbf{5 . 7 7}$ & 0.3601 & 0.3083 & $\mathbf{7 . 3 0}$ \\
\hline VN-4 & $\mathbf{5 . 8 3}$ & 0.3498 & 0.3064 & $\mathbf{5 . 9 0}$ \\
\hline Csengődi 8 & $\mathbf{5 . 9 0}$ & 0.3541 & 0.3079 & $\mathbf{7 . 0 0}$ \\
\hline Csengődi 12 & $\mathbf{5 . 9 9}$ & 0.3529 & 0.3079 & $\mathbf{5 . 4 0}$ \\
\hline
\end{tabular}

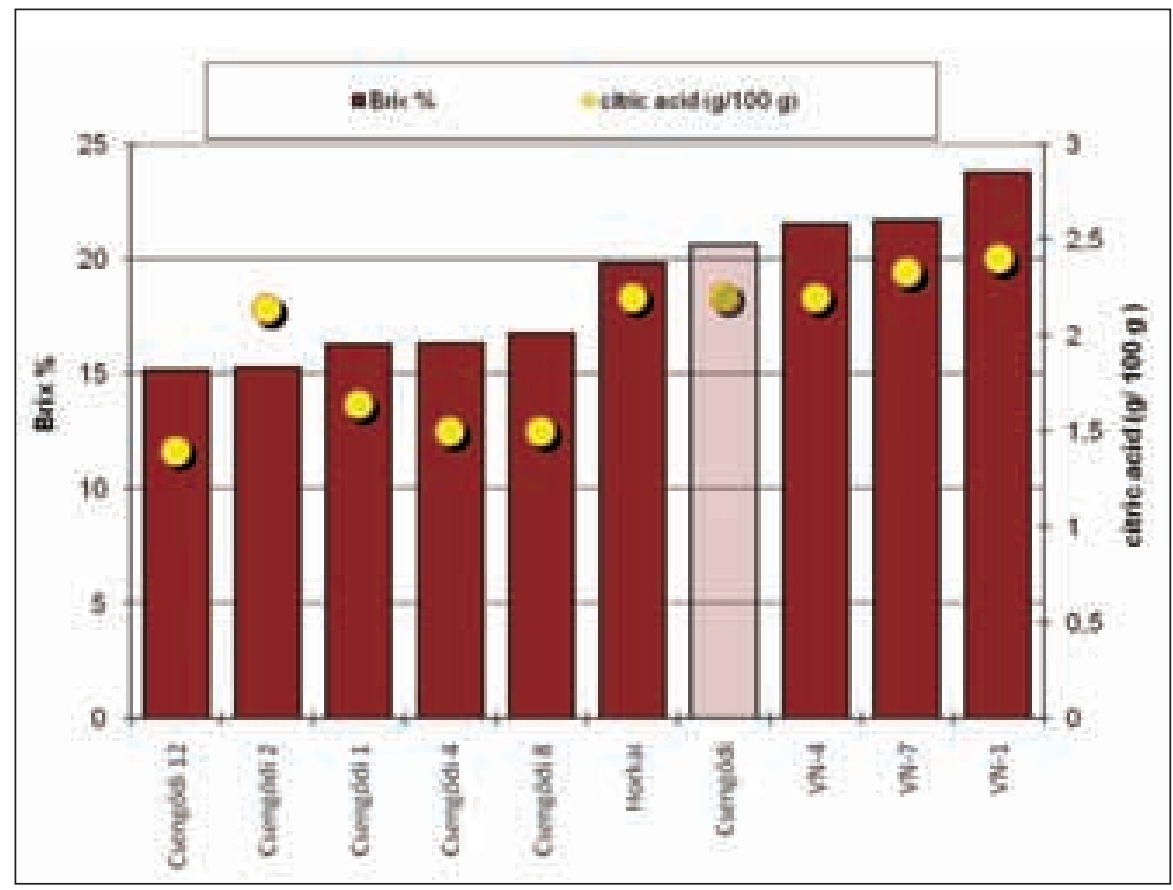

Figure 3. Brix \% and citric acid of resistant sour cherry clones (Pallag-Újfehértó, 2014) 
As a general rule with advanced ripening Brix \%, cirtic acid and PharM is increasing, while colour Y, firmness and stem detachment force is decreasing. Anthocyanin capacity is not correlated to fruit colour.

\section{Conclusions}

According to preliminary results, the disease resistant 'Csengődi' clones have more Brix \% and antioxidant capacity and have fewer citric acid. According to our results all clones have lower Brix \% and citric acid content. 'Csengődi 1', VN-4 and Csengődi 2 have lower anthocyanin capacity, other clones have higher values. Despite of their low fruit weight VN-7, Horkai and 'Csengődi' 4 have excellent fruit quality. Csengődi 2 and Csengődi 8 have big fruit size. Horkai has excellent fruits and ripen homogenicly. Taking these fruit characteristics we can choose the adequate clones for our own purpose.

\section{Acknowledgements}

This research was supported by the European Union and the State of Hungary, cofinanced by the European Social Fund in the framework of TÁMOP 4.2.4. A/2-11-1-20120001 'National Excellence Program'.

\section{References}

Apostol J. (1990): Biomeggy - az első ellenálló meggyfajta. Kertészet és Szőlészet 39: 17. 3. p.

Apostol J. (1994): A meggynemesítés eredményei Budatétényben. Kandidátusi értekezés. MTA, Budapest.

Apostol J. (2003): Cseresznye- és meggynemesítés, a fontosabb fajták leírása. [In: Hrotkó K. (szerk.): Gyümölcsfaiskola.] Mezögazda Kiadó, Budapest.
Brózik S.; Kállay T-né (2000): Csonthéjas gyümölcsfajták. Mezőgazda Kiadó, Budapest.

Gonda I. (2010): Meggy. [In: Gonda I. (szerk.): Csonthéjas gyümölcsfák metszése.] DE AMTC KFI, Gonda István Betéti Társaság, Debrecen.

Holb, I.J. (2004): The brown rot fungi of fruit crops (Monilinia spp.): III. Important features of their disease control (Review), International Journal of Horticultural Science, 10 (4): 31-48.

Holb, I. J. (2006): Possibilities of brown rot management in organic stone fruit production in Hungary. International Journal of Horticultural Science, 12 (3): 87-91.

Holb, I. J. (2009): Some biological features of cherry leaf spot (Blumeriella jaapii) with special reference to cultivar susceptibility. International Journal of Horticultural Science, 15 (1-2): 91-93.

Horkai ZS. (2002): Meggytípusok értékelése Feketicsen. Diplomamunka, Szent István Egyetem, Budapest.

Nyéki J., Soltész M., Popovics L., Szabó T., Thurzó S., Holb I., Fári M.G., Veres ZS., Harsányi G., Szabó Z. (2005): Strategy of the sour cherry verticum in the NorthernGreat Plain Region of Hungary. International Journal of Horticultural Science, 11 (4): 7-31.

Porpáczy A. (1964): A korszerü gyümölcstermelés elméleti kérdései. Mezőgazdasági Kiadó, Budapest.

Soltész M. (1997): Integrált gyümölcstermesztés. Mezőgazda Kiadó, Budapest.

Soltész M. (1998): Gyümölcsfajtaismeret és használat. Mezőgazda Kiadó, Budapest.

Soltész M. (2004): Meggy. [In: Papp J. (szerk): A gyümölcsök termesztése.] Mezőgazda Kiadó, Budapest.

Soltész M., Nyéki J., Papp J., Szabó Z. (2003): Hungarikum gyümölcsök. 111-139. [In: Nyéki J., Papp J. (Szerk.): Kertészeti hungarikumok.] Budapest: MTA Társadalomkutató Központ.

Szabó, T (2007): Az északkelet-magyarországi meggy tájfajta szelekció eredményei és gazdasági jelentősége. Doktori értekezés. Budapesti Corvinus Egyetem. 